\title{
PENGARUH PERENCANAAN STRATEGI DAN KINERJA PERUSAHAAN TERHADAP KEUNGGULAN BERSAING TOKO BUSANA MUSLIM DI KOTA PONTIANAK
}

\author{
Ema Elisa \\ IAIN Pontianak \\ emaelisa@yahoo.co.id
}

\begin{abstract}
ABSTRAK
Tujuan penelitian ini adalah untuk Menguji dan menganalisis pengaruh dari perencanaan strategi terhadap keunggulan bersaing pada Toko Busana Muslim Di Kota Pontianak . Menguji dan menganalisis pengaruh dari kinerja perusahaan terhadap dalam keunggulan bersaing Toko Busana Muslim Di Kota Pontianak. Menguji dan menganalisis pengaruh dari perencanaan strategi terhadap keunggulan bersaing dengan kinerja perusahaan. Penelitian ini menggunakan pendekatan kuantitatif dengan metode penelitian yang digunakan dalam penulisan ini adalah metode asosiatif kausal. Populasi semua owner dengan sampel sebesar 70 responden owner toko busana muslim di kota Pontianak. Berdasarkan hasil penelitian dapat disimpulkan bahwa secara parsial perencanaan strategi dan kinerja perusahaan signifikan terhadap kenggulan bersaing. Hasil pengujian regresi dengan tingkat signifikansi $0,000<0,05$ dan t-Statistik bernilai positif $(0,330)$ Variabel perencanaan strategi dan untuk hasil pengujian regresi dengan tingkat signifikansi 0,046 $<0,05$ dan t-Statistik bernilai positif sebesar $(0,277)$ pada kinerja perusahaan. sedangkan secara simultan, perencanaan strategi dan kinerja perusahaan berpengaruh signifikan dalam meningkatkan keunggulan bersaing yang dapat dilihat dari hasil pengujian regresi dengan tingkat signifikansi $0,000<0,05$ dan F-Statistik bernilai positif $(38,493)$.

Kata Kunci : Pengarub Perencanaan Strategi, Kinerja Perusahaan, keunggulan bersaing, Toko Busana Muslim Dikota Pontianak.
\end{abstract}

\begin{abstract}
The purpose of this study is to Test and analyze the effect of strategic planning on competitive advantage in Muslim Clothing Stores in Pontianak City. Test and analyze the effect of company performance on competitive advantages of Muslim Clothing Stores in Pontianak City. Test and analyze the effect of strategic planning on competitive advantage with company performance. This research uses a quantitative approach with the research method used in this paper is a causal associative method. The population of all owners with a sample of 70 respondents owner of a Muslim clothing store in the city of Pontianak. Based on the results of the study it can be concluded that partially strategic planning and firm performance are significant for competitive foe. Regression test results with a significance level of $0,000<0.05$ and tStatistic values are positive (0.330) Variables for strategic planning and for the results of regression testing with a significance level of $0.046<0.05$ and t-Statistic values of (0.277) positive on company performance. while simultaneously, strategic planning and company performance have a significant effect in increasing competitive advantage which can be seen from the results of regression testing with a significance level of $0,000<0.05$ and the F-Statistic value is positive $(38,493)$.

Keywords: Effect of Strategic Planning, Company Performance, competitive advantage, Muslim Clothing Store in Pontianak City
\end{abstract}

Iltizam Journal Of Shariah Economic Research, Vol. 4, No. 1, 2020

Fakultas Ekonomi dan Bisnis Islam UIN Sulthan Thaha Saifuddin Jambi

E-ISSN: 2598-2540, P-ISSN: 2598-2222 


\section{PENDAHULUAN}

Perkembangan fashion baju busana muslim di tanah air saat ini mengalami kemajuan yang sangat signifikan, bahkan banyak pengamat dunia fashion yang memprediksikan Indonesia akan menjadi pusat produksi dunia beberapa tahun ke depan. Bukti nyata akan hal ini adalah adanya penggunaan baju muslim yang sudah terlihat universal, bukan hanya pada saat acara keagamaan saja, namun juga dalam aktivitas sehari-hari, mulai dari ibu rumah tangga, pebisnis, pesohor tanah air hingga yang para muslimah yang bekerja di kantor. Mayoritas penduduk Indonesia beragama Islam, maka baju busana muslim bukan termasuk barang yang susah untuk didapatkan. Bahkan saat ini seiring dengan perkembangan mode, beragam jenis serta model baju muslim menjadi sangat banyak berada di pasaran, terutama bagi para muslimah. Bahkan kabarnya, perkembangan industri yang sangat hebat ini juga mulai dilirik oleh beberapa produsen dari luar Indonesia.

Trend belanja busana ini tentu saja tidak akan bertahan lama jika tidak disertai dengan manajemen yang baik dan analisis daya saing terhadap industri busana yang sudah ada. Strategi yang tepat untuk mempertahankan model usaha seperti ini, mutlak diperlukan agar dapat menampung kreativitas produk busana yang biasanya dibuat dalam skala kecil dan terbatas tersebut. Perkembangan dunia usaha dalam bidang perusahaan industri yang berubah dengan cepat dan metode perencanaan strategis yang memberikan perhatian besar dalam mengantisipasi berbagai perubahan yang terjadi di masa depan, maka penerapan perencanaan strategis merupakan suatu kebutuhan yang mendesak dan harus dilaksanakan semaksimal mungkin, mengingat lingkungan juga selalu berubah dan masa depan kian sulit diprediksikan. ${ }^{1}$ Perencanaan strategis adalah proses memutuskan program-program yang akan dilaksanakan oleh organisasi dan perkiraan jumlah sumber daya yang akan dialokasikan pada setiap program jangka panjang selama beberapa tahun ke depan. Hasil dari proses perencanaan strategi berupa dokumen yang dinamakan strategic plan yang berisi informasi tentang program-program beberapa tahun yang akan datang. ${ }^{2}$

\footnotetext{
${ }^{1}$ Kurniawan, A., Nurdin, B., \& Indrianty, S. Analisis Pengarub Faktor Manajerial, Faktor Lingkungan, Kultur Organisasi Dan Perencanaan Strategis Terbadap Keunggulan Bersaing PT Semen Tonasa. Basri, dalam Kurniawan, 2019: 37

2 Rusniati \& Ahsanul H. (2014). Perencanaan Strategi dalam Perspektif Organisasi. Jurnal INTEKNA, Vol 2 (2), 102-209.
} 
Berkaitan antara pengaruh kinerja perusahaan terhadap keunggulan bersaing dapat tercapai ketika kemampuan manajemen dan menggunakan kreasi dan mengimplentasikan strategi agar tahan pada keunggulan yang banyak terjadi peniruan, mampu menciptakan faktor hambatan dalam jangka waktu yang lama dalam penelitian Keunggulan bersaing yang berkelanjutan dapat dicapai apabila kemampuan manajemen dalam berkreasi dan mengimplementasikan sebuah strategi yang tahan akan persaingan imitasi dan mampu menciptakan persaingan dalam jangka waktu yang lama .Penelitian ini menarik untuk dilakukan karena ingin mengetahui Bagaimana perencanaan strategi berpengaruh signifikan terhadap keunggulan bersaing pada Toko Busana Muslim Di Kota Pontianak?,Bagaimana kinerja perusahaan berpengaruh signifikan terhadap keunggulan bersaing pada Toko Busana MusLim Di Kota Pontianak? Dan Bagaimana perencanaan strategi dan kineja perusahaan berpengaruh signifikan terhadap keunggulan bersaing pada Toko Busana Muslim Di Kota Pontianak?

\section{KAJIAN TEORI}

\section{A. Perencanaan Strategi}

Perencanaan hendaknya memerhatikan sesuatu apa yang dikerjakan pada masa lalu untuk merencanakan sesuatu pada masa yang akan datang. ${ }^{3}$ Perencanaan strategi adalah usaha yang sistematis dan formal dari sebuah peruashaan untuk menentukan tujuan perusahaan, aturan, dan strategi yang melibatkan pembuatan rencana yang detil untuk mengimplementasikan aturan dan strategi untuk mencapai tujuan utama perusahaan. ${ }^{4}$ Pengertian lain disampaikan oleh Razan dikutip dari elmani dan Esfaghansary yang mengatakan bahwa adalah sesuatu yang dirancang untuk mencapai tujuan komprehensif sebuah perusahaan, sehingga dapat memastikan eksekusi misi perusahaan.Berdasarkan menurut para ahli di atas, dapat disimpulkan perencanaan strategi merupakan sebuah langkah awal dalam memutuskan kegiatan apa, bagaimana melaksanakannya, kapan dan oleh siapa. hal ini dilakukan untuk menentukan tujuan organisasi kedepannya. Hlm.98

${ }^{3}$ Muhammad Munir \& Wahyu Ilahi. 2006. Manajemen Dakwah. jakarta: Kencana Prenada media group.

4 Arasa, R., K'Obonya. P. (2012). The Relationship between Strategic Planning and Firm Performance. International Journal of Humanities and Social Science, Vol. 2 No. 22, 201-2013. 
Apabila dilaksanakan dengan benar dan didukung oleh komitmen pimpinan, perencanaan strategik dapat memberi manfaat bagi organisasi sebagai berikut: ${ }^{5}$

1. Perencanaan strategik dapat memperkuat "critical mass" menjadi team yang kompak, karena diarahkan untuk menganut nilai-nilai pokok, sistem utama dan tujuan bersama

2. Perencanaan strategis dapat membantu untuk mengoptimisasikan "performance" organisasi. "Perencanaan strategik dapat membantu pimpinan untuk selalu memusatkan perhatian dan menganut kerangka bagi upaya perbaikan secara kontinu. Perencanaan strategik selalu membantu pimpinan memusatkan perhatian agar perbaikan dan inovasi yang direncanakan dapat dievaluasi seberapa jauh kegiatan tersebut mendukung "Vision" bagi organisasi. Selanjutnya perencanaan strategik juga dapat menyediakan kerangka guna memprioritaskan, menata dan mengintegrasikan upaya perbaikan.

3. Perencanaan strategi memberikan pedoman bagi pengambilan keputusan sehari-hari. Perencanan strategik tidak hanya membimbing usaha besar saja, melainkan juga membimbing kegiatan sehari-hari. Perencanaan strategik diharapkan mempengaruhi seluruh tingkat dalam organisasi, dengan mengkomunikasikannya secara jelas mengenai tujuan strategik pada seluruh tingkat tersebut.

4. Perencanaan strategi selalu memberikan kemudahan untuk mengukur kemajuan organisasi dalam usaha mencapai tujuannya untuk memperbaiki kualitas dan produktivitas.

\section{B. Kinerja Perusahaan}

Kinerja perusahaan saat ini secara keseluruhan relatif terhadap perusahaan lain di dalam industry dalam konteks kualitas produk dan jasa, moral pegawai, skil pegawai, produktivitas dan efisiensi tenaga kerja, dan tingkat keuntungan yang dipahami sebagai peningkatan keseluruhan keuntungan yang didasarkan pada pendapatan yang dihasilkan dari penjualan produk dan jasa. ${ }^{6}$

Kinerja adalah hasil atau tingkat keberhasilan seseorang secara keseluruhan selama periode tertentu dalam melaksanakan tugas dibandingkan dengan berbagai kemungkinan, seperti standar hasil kerja, target atau sasaran atau

\footnotetext{
${ }^{5}$ Bryson., J., M, (2001). Perencanaan Strategis Bagi Organisasi Sosial, Pustaka Pelajar Yogyakarta. Hlm.5

${ }^{6}$ Natasha, P \& Devie. (2013). Analisa Pengaruh Strategic Planning Terhadap Keunggulan Bersaing dan Kinerja Perusahaan. Bussines accounting review, Vol 1(2), 185-195.
} 
kriteria yang telah ditentukan terlebih dahulu telah disepakati bersama. ${ }^{7}$ kinerja adalah gambaran mengenai tingkat pencapaian pelaksanaan suatu kegiatan/ program/ kebijakan dalam mewujudkan sasaran, tujuan, visi, dan misi organisasi yang tertuang dalam strategi planning atau organisasi. ${ }^{8}$

Berdasarkan menurut para ahli di atas, dapat disimpulkan kinerja perusahaan merupakan tingkat pencapaian pelaksanaan suatu kegiatan untuk mencapai target atau kriteria yang telah ditentukan terlebih dahulu yang telah disepakati bersama.Karakteristik Kinerja Perusahaan. Karakteristik orang yang mempunyai kinerja tinggi adalah sebagai berikut: ${ }^{9}$ memiliki tanggung jawab pribadi yang tinggi, berani mengambil dan menanggung resiko yang dihadapi, memiliki tujuan yang realistis, memiliki rencana kerja yang menyeluruh dan berjuang untuk merealisasi tujuannya, memanfaatkan umpan balik (feed back) yang kongkrit dalam seluruh kegiatan kerja yang dilakukannya, mencari kesempatan untuk merealisasikan rencana yang telah diprogramkan..Penilaian kinerja menjadi penting adanya dalam perusahaan. Karyawan yang merasa diapresiasi hasil kerjanya akan menunjukkan sikap kerja yang lebih positif. Sebaliknya, karyawan yang merasa kurang terhargai hasil kerja oleh perusahaan akan memberikan sikap yang kurang mendukung organisasi. Oleh karena itu, tahap penilaian kinerja menjadi sangat penting bagi karyawan.

\section{Keunggulan Bersaing}

Keunggulan bersaing adalah sesuatu yang memungkinkan sebuah perusahaan memperoleh keuntungan yang lebih tinggi dibandingkan dengan rata-rata keuntungan yang diperoleh pesaing dalam industri. Semakin kuat keunggulan yang dimiliki akan semakin tinggi keuntungan yang diperoleh perusahaan dan begitu pula sebaliknya. ${ }^{10}$.keunggulan bersaing merupakan perkembangan dari nilai yang mampu diciptakan perusahaan untuk pembelinya. ${ }^{11}$

Konsep keunggulan bersaing (Competitive Advantage), tidak dapat dipahami dengan cara memandang sebuah per.usahaan sebagai suatu keseluruhan, tetapi

7 Rivai dan Basri. (2005) manajemen sumber daya manusia untuk perusahaan, Jakarta:Rajagrafindo Persada. Hlm. 50

${ }^{8}$ Mahsun. (2013) Teks dalam Pembelajaran Bahasa Indonesia. Jakarta: Raja Grafindo Persada. Hlm, 25

9 A. P. Mangkunegara. 2016. Manajemen Sumber Daya Manusia Perusahaan. Bandung: PT. Remaja Rosdakarya. Hlm, 68

10 Amin wahyudi,2006, analisis pengaruh gaya kepimpinan, motivasi dan lingkungan kerja terhadap kinerja pegawai. Hlm, 61

11 Dirgantoro, crown, (2001). Manajemen stratejik konsep, kasus dan implementasi. Grasindo, jakarta. Hlm,159 
harus dari asal keunggulan bersaing itu yaitu berbagai aktivitas berlainan yang dilakukan oleh perusahaan dalam mendesain, memproduksi, memasarkan, menyerahkan dan mendukung produknya. Analisis rantai nilai lebih tepat untuk meneliti keunggulan bersaing daripada nilai tambah (harga jual dikurangi biaya pembelian bahan baku), karena analisis ini dapat mengetahui nilai-nilai yang dimiliki semua aktivitas, sehingga dapat diketahui asal atau sumber dari keunggulan bersaing itu.Strategi Keunggulan Bersaing. ${ }^{12}$ Strategi yaitu rencana berskala besar, bertujuan kemasa depan untuk berinteraksi dengan kondisi persaingan demi memcapai tujuan perusahaan. Strategi yaitu program umum untuk pencapaian tujuan-tujuan organisasi dalam pelaksana misi. Keunggulan bersaing adalah kumpulan strategi untuk menentukan keunggulan suatu perusahaan dari persaingan diantara perusahaan lain. ${ }^{13}$

\section{METODE PENELITIAN}

Pendekatan penelitian atau sering disebut paradigma penelitian merupakan kerangka berpikir yang menjelaskan bagaimana cara pandang peneliti terhadap fakta kehidupan sosial dan perlakuan peneliti terhadap ilmu atau teori. ${ }^{14}$ Terkait dengan latar belakang, rumusan masalah, dan tujuan penelitian, maka penelitian ini menggunakan pendekatan kuantitatif dengan metode penelitian yang digunakan dalam penulisan ini adalah metode asosiatif kausal..Menurut Arikunto Metode asosiatif kausal adalah permasalahan yang menyatakan hubungan bersifat sebab akibat. jadi disini ada variabel independen ( variabel yang mempengaruhi) dan variabel dependen (dipengaruhi) yang menjadi variabel bebas dalam penelitian ini adalah perencanaan strategi kinerja perusahaan dan yang menjadi variabel terikat adalah keunggulan bersaing. .Lokasi penelitian ini dilaksanakan di Toko Busana Muslim yang beralamat di Kota Pontianak .Populasi dalam penelitian ini adalah owner yang kebetulan berada ditoko busana muslim. Dalam penelitian ini peneliti menggunakan tekhnik penentuan sampel dengan non probalyti sampling dan tekhnik yang digunakan adalh tekhnik sampling insidental. sedangkan sampling insedental merupakan tekhnik pengambilan

12 Istanto., Y, (2010), Pengaruh Strategi Keunggulan Bersaing dan Positioning Terhadap Kinerja. Buletin Ekonomi, V01 8 (2) 124-135.

${ }^{13}$ Nurma., M, (2013). Strategi Keunggulan Bersaing Untuk Meningkatkan Jumlah Nasabah di PT, PBRS Mitra Cahaya Indonesia Ngalik Sleman. Skripsi Universitas Islam Negri Sunan Kalijaga Yogyakarta. (2013). Hlm, 125

14 Noor,juliansyah. (2011) Metodologi Penelitian: Skripsi, Tesis, Disertasi, dan Karya Ilmiah. Jakarta: Kencana hlm, 33 
sampel berdasarkan kebetulan yaitu siapa saja yang secara kebetulan bertemu dengan peneliti bisa dijadikan sampel bila dipandang orang yang kebetulan ditemui ini cocok sebagai sumber data menurut Sugiyono Dalam penelitian ini, peneliti mengambil sampel owner yang sedang menjaga toko busana muslim nya sebanyak 70 responden.

Untuk mendapatkan data kuantitatif peneliti menggunakan kuesioner (angket) Secara umum teknik pengumpulan data terdiri dari studi kepustakaan, observasi, kuesioner, wawancara dan dokumen peneliti menggunakan teknik dan alat pengumpulan data berupa :Komunikasi tidak langsung, dan Dokumentasi .Adapun teknik analisis data yang digunakan dalam penelitian ini adalah sebagai berikut:Uji Instrumen Kuesioner, ${ }^{15}$ kuesioner yang telah disusun hendaknya dilanjutkan dengan melakukan uji kusioner. Uji kuesioner secara kuantitatif dapat dilakukan melalui uji validitas dan realibitas. Lalu melakukan Uji Asumsi Klasik Sebelum melakukan pengujian hipotesis dengan menggunkaan regresi linier berganda perlu dilakukan terlebih dahulu pengujian asumsi klasik, Uji asumsi klasik terdiri atas.

\section{Uji Normalitas}

Uji linieritas

Uji Autokorelasi Merupakan korelasi anatara anggota seri observasi yang disusun menurut urutan waktu ( seperti data time series) atau menurut urutan tempat atau ruang ( seperti data cross section) atai autokorelasi dalam suatu model regresi dilakukan melalui pengujian nilai uji Durbin Watson test dengan ketentuan sebagai berikut: ${ }^{16}$

Ho : tidak ada autokorelasi baik positif maupun negatif

$\mathrm{Ha}$ : ada autokorelasi baik positif maupun negatif

Maka jika :
$\mathrm{dw}<\mathrm{dl}$
: menolak Ho
$\mathrm{dw}>4-\mathrm{dl}$
: menolak Ho
$\mathrm{du}<\mathrm{d}-4 \mathrm{du}$
: tidak menolak Ho (menerima $\mathrm{Ha}$ )
$\mathrm{dl}<=\mathrm{dw}<=\mathrm{du}$
: pengujian tidak menyakinkan

${ }^{15}$ Husein Umar. 2012. Metode Penelitian untuk Skripsi dan Tesis. Jakarta: Rajawali. Hlm, 165

16 Ghazali, Imam. (2011). Aplikasi Analisis Multivariate Dengan Program IBM SPSS 19. Uneversitas Diponegoro. Semarang. 
4- du $<=\mathrm{dw}<=4-\mathrm{dl} \quad$ : pengujian ragu- ragu



\section{Gambar Pengujian Autokorelasi}

Sumber : Sugiyono (2015)

Uji heteroskedastisitas

Pengujian dilakukan dengan uji ARCH LM teks, dimana dengan melihat nilai prob. F atatistic (F hitung). Apabila nilai pron $>\mathrm{F}$ hitung $>0,05$ $(5 \%)$ maka Ho diterima yang artinya tidak terjadi heteroskedastisitas, sedangkan apabila nilai Prob. F hitung $<0,05$ maka Ho ditolak yang artinya terjadi heteroskedastisitas.

Uji multikolonlinieritas

Uji ini dignakan untuk mengetahui apakah pada model regresi ditemukan adanya korelasi antar variabel independen. Jika terjadi korelasi, mka dinamakan terdapat problem multikolinieritas (Multiko).

Selanjutnya dilakukan Uji Koefisisen Untuk menguji apakah vaariabel independen mempunyai pengaruh yang signifikan atau tidak terhadap variabel dependen, maka diperlukan uji koefisien.

Koefisien Determinasi (R2)

Uji Signifikan Parameter Individual ( Uji Statistik T)

Dasar pengambilan keputusan digunakan dalam uji $\mathrm{T}$ adalah sebagai berikut.

jika nilai probalitas signifikan $>0,05$, maka hipotetsis ditolak. Hipotetsis ditolak mempunyai arti bahwa variabel independn tidak berpengaruh signifikan terhadap variabel dependen. 
jika nilai probabilitas signifikansi $<0,05$, maka hipotetsis diterima. hipotesis tidak dapat ditolak mempunyai arti bahwa variabel independen berpengaruh signifikan terhadap variabel dependen.

Uji Signifikansi simultan (Uji Statistik F)

Untuk menguji hipotesis ini digunakan statistik F dengan kriteria pengambilan keputusan sebagai berikut:

jika nilai f lebih besra dari 4 maka Ho ditolak padadreajat kepercayaan 5\% dengan kata lain kita menerima hipotesis alternatife, yang menyatakan bahwa 55 semua variabel independen secara serentak dan signifikan mempengaruhi varaibel dependen.

membandingkan niali $\mathrm{F}$ hasil perhitngan dengan $\mathrm{F}$ meneurut tabel. Bila nilai $\mathrm{F}$ Hitung lebih besar dari pada nilai $\mathrm{F}$ tabel, maka Ho ditolak dan diterima Ha.

Lalu di lakukan uji Analisis Regresi Linier Berganda. Analiais regresi linier berganda adalah meramalkan bagaimana keadaan (naik turunnya) variabel dependen, bila dua atau lebih variabel independen sebagai faktor prediktor di manipulasi ( dinaik turunkan nilainya). jadi analisis regresi berganda akan dilakukan bila jumlah variabel independennya minimal 2 persamaan regresi linier berganda yang ditetapkan adalah sebagai berikut. ${ }^{17}$

$$
\text { Rumus : } Y=a+b^{1} x^{2}+b^{2} x^{2}+€
$$

Jadi analisis regresi ganda akan dilakukan bila jumlah variabel independen nya minimal 2. pengujian dalam penelitian ini dilakukan secara dengan menggunakan Software SPSS.

keterangan :

$\mathrm{Y}=$ Keunggulan bersaing

$\mathrm{a}=$ Koefisien Konstanta

$\mathrm{b}_{1} \mathrm{~b}_{2}=$ Koefisien Regresi

$\mathrm{X}_{1}=$ Perencanaan Strategi

$\mathrm{X}_{2}=$ Kinerja perusahaan

$€=$ Error, variabel gangguan

${ }^{17}$ Sugiyono, (2013). Metode Penelitian Kuantitatif Kualitatif dan R\&D. Bandung: Alfabeta. Hlm, 277 


\section{HASIL DAN PEMBAHASAN}

\section{HASIL PENELITIAN}

\section{Uji Asumsi Klasik}

Uji Normalitas

Uji Normalitas bertujuan untuk mengji amankah dalam model regresi. variabel penganggu atau residual memiliki distribusi normal. kriteria pengujian normalitas adalh jika nilai signifikansi $>0,05$ maka data berdistribusi normal.

Uji Normalitas

\begin{tabular}{|l|l||l|}
\hline $\begin{array}{l}\text { One-Sample Kolmogorov-Smirnov } \\
\text { Test }\end{array}$ & & \\
\hline & & $\begin{array}{l}\text { Unstandardized } \\
\text { Residual }\end{array}$ \\
\hline $\mathrm{N}$ & Mean & 70 \\
\hline Normal Parameters ${ }^{\mathrm{a}, \mathrm{b}}$ & .0000000 \\
\hline & $\begin{array}{l}\text { Std. } \\
\text { Deviation }\end{array}$ & 2.02398093 \\
\hline Most Extreme Differences & Absolute & .118 \\
\hline & Positive & .118 \\
\hline & Negative & -.094 \\
\hline Kolmogorov-Smirnov Z & & .983 \\
\hline Asymp. Sig. (2-tailed) & & .289 \\
\hline a. Test distribution is Normal. & & \\
\hline Sumber: hasil olahan SPSS 17.0 Tahun & & \\
2019 & & \\
\hline
\end{tabular}

Berdasarkan hasil pengujian normalitas dengan menggunakan SPSS 17.0 Tahun 2018 pada table diatas diperoleh nilai kolmogrov-smirnow >0,05 yaitu 0,289 sehingga dapat disimpulkan bahwa data penelitian berdistribusi normal. 
Uji Linearitas

Uji linieritas digunakan untuk melihat apakah spesifikasi yang dugnakan sudaah benar atau tidak. ${ }^{18}$ kriterian pengujian linieritas adalah jika nilai signifikansi $>0,05$ maka hubungan antara variabel bebas dan variabel terikat adalah linear.

Variabel perencanaan strategi (x1)

Uji Linieritas

\begin{tabular}{|c|c|c|c|c|c|c|c|}
\hline $\begin{array}{c}\text { ANOVA } \\
\text { Table }\end{array}$ & & & & & & & \\
\hline & & & $\begin{array}{l}\text { Sum of } \\
\text { Squares }\end{array}$ & Df & $\begin{array}{l}\text { Mean } \\
\text { Square }\end{array}$ & $\mathrm{F}$ & Sig. \\
\hline $\mathrm{KB} * \mathrm{PS}$ & $\begin{array}{l}\text { Between } \\
\text { Groups }\end{array}$ & (Combined) & 364.530 & 14 & 26.038 & 5.895 & $\mid .000$ \\
\hline & & Linearity & 307.302 & 1 & 307.302 & 69.579 & .000 \\
\hline & & $\begin{array}{l}\text { Deviation from } \\
\text { Linearity }\end{array}$ & 57.228 & 13 & 4.402 & .997 & 467 \\
\hline & $\begin{array}{l}\text { Within } \\
\text { Groups }\end{array}$ & & & 55 & 4.417 & & \\
\hline & Total & & 607.443 & 69 & & & \\
\hline
\end{tabular}

Sumber: hasil olahan SPSS 17.0 Tahun 2019

Hasil Uji linearitas dapat dilihat pada output diatas diketahui bahwa nilai signifikansi sebesar 0,467 dengan demikian $>0,05$. Artinya hal ini membuktikan bahwa antara variabel X1 dan Y menujukkan adanya lineari

${ }^{18}$ Ibid ghazali hlm,166 
Variabel Kinerja Perusahaan (x2)

Uji Linieritas

\begin{tabular}{|l|l|l|l|l|l|l|l|}
\hline $\begin{array}{l}\text { ANOVA } \\
\text { Table }\end{array}$ & & & $\begin{array}{l}\text { Sum of } \\
\text { Squares }\end{array}$ & $\begin{array}{l}\text { Mean } \\
\text { df }\end{array}$ & Square & F & Sig. \\
\hline KB* KP & $\begin{array}{l}\text { Between } \\
\text { Groups }\end{array}$ & (Combined) & 326.346 & 11 & 29.668 & 6.121 & .000 \\
\hline & & Linearity & 255.421 & 1 & 255.421 & 52.702 & .000 \\
\hline & $\begin{array}{l}\text { Weviation from } \\
\text { Githin } \\
\text { Groups }\end{array}$ & 70.925 & 10 & 7.093 & 1.463 & .177 \\
\hline & Total & & 281.097 & 58 & 4.847 & & \\
\hline
\end{tabular}

Sumber: hasil olahan SPSS 17.0 Tahun 2019

hasil uji linieritas dengan SPSS 17.0 dapat dilihat pada output tabel diatas diketahui bahwa nilai signifikansi sebesar 0,177 dengan demikian > 0,05. Artinya hal ini membuktikan bahwa antara dua variabel menunjukkan adanya linieritas.

Uji Heteroskedastisitas

Dari residual satu pengamatan ke pengamatan yang lain. jika varians dari residual satu pengamatan ke pengamatan lain tetap maka disebut homoskedastisitas dan jika berbeda disebut heteroskedastisitas. ${ }^{19}$ dalam skripsi jamilah

${ }^{19}$ Ibid ghazali, hlm, 139 
Uji Heteroskedastisitas

\begin{tabular}{|c|c|c|c|c|c|c|}
\hline Coefficients $^{a}$ & & & & & & \\
\hline Model & & $\begin{array}{l}\text { Unstandardized } \\
\text { Coefficients }\end{array}$ & & $\begin{array}{l}\text { Standardized } \\
\text { Coefficients }\end{array}$ & $\mathrm{T}$ & Sig. \\
\hline & & B & $\begin{array}{l}\text { Std. } \\
\text { Error }\end{array}$ & Beta & & \\
\hline 1 & (Constant) & 1.970 & 1.381 & & 1.426 & .158 \\
\hline & PS & .045 & .053 & .158 & .856 & .395 \\
\hline & $\mathrm{KP}$ & -.092 & .088 & -.193 & $\begin{array}{l}- \\
1.042\end{array}$ & .301 \\
\hline $\begin{array}{l}\text { a. Dependent } \\
\text { Variable: } \\
\text { Abs_RES }\end{array}$ & & & & & & \\
\hline
\end{tabular}

Sumber: hasil olahan SPSS 17.0 Tahun 2019

Berdasarkan tabel 4.16 diatas menunjukkan bahwa semua variabel mempunyai berdasarkan tabel 4.15 menunjukakn bahwa semua variabel perencanaan strategi $(\mathrm{x} 1)$ sebesar $0,395>0,05$, nilai signifikansi kinerja perusahaan $0,301>0,05$, maka dapat disimpulkan bahwa variabel bebas tidak terjadi heteroskedastisistas atau homoskedastisistas.

Uji Autokorelasi

Pengujian ini dilakukan untuk mengetahui ada tidaknya kesalahan penganggu (error term) pada pengamatan sebelum dengan penganggu pada periode berikutnya. persyaratan uji dengan menggunakam tabel DurbinWatson, (Imam Ghozali, 2012 dalam skripsi Syf, qafilla).

Uji Autokorelasi

\begin{tabular}{|c|c|c|c|c|}
\hline $\begin{array}{l}\text { Angka Durbin } \\
\text { Watson }\end{array}$ & $\begin{array}{l}\text { Du tabel }(k=2 ; \\
n=70)\end{array}$ & $\begin{array}{l}4 \\
\text { dutabel }\end{array}$ & $\begin{array}{l}\text { Dl tabel }(\mathrm{k}=2 ; \\
\mathrm{n}=70)\end{array}$ & $\begin{array}{l}4-\mathrm{dl} \\
\text { tabel }\end{array}$ \\
\hline 2.024 & 1.671 & 2,052 & 1.552 & 2.446 \\
\hline
\end{tabular}

Sumber: hasil olahan SPSS 17.0 Tahun 2019

hasil pengujian diperoleh DW sebesar 2,024. sedangkan dari tabel Durbin Watson untuk $\mathrm{n}=70$ dan $\mathrm{k}=2$ diperoleh $\mathrm{dL}=1,552$ dan hasil $4-\mathrm{du}=4$ $1,671=2,052$ untuk $4-\mathrm{dL}=4-1,552=2,446$ dan $4-$ du tabel $=2,052$ 
sehingga dapat disimpulkan bahwa tidak ada kecenderungan terjadi autokorelasi dalam persamaan regresi.

Uji Multikolineieritas

Uji ini bertujuan untuk menguji apakah model regresi ditemukan adanya korelasi antar antar variabel independen. ${ }^{20}$ untuk mendeteksi ada atau tidaknya multikolineritas didalam regresi dapat dilihat dari nilai tolerance dan varianceinflation factor (VIF). dengan ketentuan sebagai berikut.

Jika nilai tolerance $<0,1$ dan nilai variance inflation factor $(\mathrm{VIF})<10$, maka dapat disimpulkan bahwa tidak ada multikolonieritas antar variabel independen nya dalam model regresi.

Jika nilai tolerance $<0,1$ dan nilai variance inflation factor $(\mathrm{VIF})>10$, maka dapat disimpulkan bahwa ada multikolonieritas antar variabel independen dalam model regresi.

Uji Multikolonieritas

\begin{tabular}{|c|c|c|c|c|c|c|c|c|}
\hline Coefficients $^{\mathrm{a}}$ & & & & & & & & \\
\hline Model & & $\begin{array}{l}\text { Unstandardized } \\
\text { Coefficients }\end{array}$ & & $\begin{array}{l}\text { Standardized } \\
\text { Coefficients }\end{array}$ & $\mathrm{T}$ & Sig. & $\begin{array}{l}\text { Collinearity } \\
\text { Statistics }\end{array}$ & \\
\hline & & $B$ & $\begin{array}{l}\text { Std. } \\
\text { Error }\end{array}$ & Beta & & & Tolerance & VIF \\
\hline 1 & $\mid($ Constant $) \mid$ & 9.363 & 2.136 & & 4.385 & .000 & & \\
\hline & PS & .330 & .081 & .516 & 4.055 & .000 & .429 & 2.329 \\
\hline & $\mathrm{KP}$ & .277 & .136 & .259 & 2.036 & .046 & .429 & 2.329 \\
\hline \begin{tabular}{|l|} 
a. Dependent \\
Variable: KB
\end{tabular} & & & & & & & & \\
\hline
\end{tabular}

Sumber: hasil olahan SPSS 17.0 Tahun 2019

Berdasrkan diatas, hasil olahan SPSS 17.0 tahun 2019 pada pengujian multikolonieritas menunjukkan bahwa, baik variabel bebas perencanaan strategi (x1), kinerja perusahaan (x2), karena tidak ada yang memiliki nilai tolerance $>0,1$ dan nilai $\mathrm{VIF}<10$, sehingga dapat disimpulkan bahwa didalam penelitian ini tidak mengalami multikolonieritas.

\footnotetext{
${ }^{20}$ Ibid ghozali. hlm, 105
} 


\section{Uji Hipotesis}

Uji hipotesis yang digunakan dalam penelitian ini adalah Uji parsial (Uji Statistik t), Uji signifikansi simultan (Uji f) dan Uji koefisien determinasi. Berikut hasil uji hipotesis dibawah ini:

Uji Signifikansi Parsial (Uji t)

Uji parsial (uji t) digunakan untuk mengukur seberapa jauh pengaruh masingmasing variabel independen dalam menerangkan variabel dependen.

Uji Parsial (uji t)

\begin{tabular}{|l|l|l|l|l|l|l|}
\hline Model & & $\begin{array}{l}\text { Unstandardized } \\
\text { Coefficients }\end{array}$ & & $\begin{array}{l}\text { Standardized } \\
\text { Coefficients }\end{array}$ & T & Sig. \\
\hline & & B & $\begin{array}{l}\text { Std. } \\
\text { Error }\end{array}$ & Beta & & \\
\hline 1 & (Constant) & 9.363 & 2.136 & & 4.385 & .000 \\
\hline & PS & .330 & .081 & .516 & 4.055 & .000 \\
\hline & KP & .277 & .136 & .259 & 2.036 & .046 \\
\hline
\end{tabular}

Sumber: hasil olahan SPSS 17.0 Tahun 2019

Berdasarkan pada tabel diatas diperoleh nilai t hitung (t-test) sebagai berikut:

Nilai $\mathrm{t}$ hitng perencanaan strategi $(\mathrm{x} 1)$ sebesar 4,385dengan nilai signifikansi $0,000<0,05$ sedangkan $t_{\text {tabel }}$ sebesar 1,994 . hal ini berarti nilai $t$ hitung $<\mathrm{t}_{\text {tabel. }}$ dengan demikian dapat diambil kesimpulan Ho ditolak, artinya perencanaan strategi berpengaruh signifikan secara individu terhadap keunggulan bersaing.

Nilai $t_{\text {tabel }}$ kinerja perusahaan (x2) sebesar 2,036 dengan nilai signifikansi $0,046<0,05$ sedangkan nilai $\mathrm{t}$ tabel sebesar1,994. hal ini berarti $\mathrm{t}_{\text {hitung }}>\mathrm{t}_{\text {tabel }}$. dengan demikian dapat diambil kesimpulan bahwa Ho ditolak, artinya kinerja perusahaan berpengaruh signifikan terhadap keunggulan bersaing.

Uji Simultan (Uji F)

Uji ini digunakan untuk mengetahui pengaruh variabel bebas secara bersama-sama (simultan) terhadap variabel terikat. 
Uji statistik F pada dasarnya menunjukkan apakah semua variabel independen atau bebas yang dimaksudkan dalam model mempunyai pengaruh secara bersama-sama terhadap variabel dependen/ terikat. ${ }^{21}$

Uji Simultan (F)

\begin{tabular}{|l|l|l|l|l|l|l|l|}
\hline ANOVA $^{\mathbf{b}}$ & & & & & \\
\hline Model & & & $\begin{array}{l}\text { Sum } \\
\text { Squares }\end{array}$ & $\begin{array}{l}\text { Mean } \\
\text { Df }\end{array}$ & Square & Sig. \\
\hline 1 & Residual & 282.658 & 67 & 4.219 & & \\
\hline $\begin{array}{l}\text { Total } \\
\text { KP, PS } \\
\begin{array}{l}\text { b. Dependent Variable: } \\
\text { KB }\end{array}\end{array}$ & 607.443 & 69 & & & \\
\hline
\end{tabular}

Sumber : hasil olahan SPSS 17.0 Tahun 2019

hasil perhitungan tabel diatas dapat nilai $\mathrm{F}_{\text {hitung }} 38,493$ dengan nilai signifikansi 0,000. sedangkan nilai $\mathrm{F}_{\text {tabel }}$ sebesar 3,13 hal ini berarti nilai $\mathrm{F}$ hitung $>F_{\text {tabel }}$ yaitu 38,439 $>$ 3,13. Selain itu nilai alfa atau signifikan juga menunjukkan angka $<$ 0,05.sehingga dapat disimpulkann bahwa Ho ditolak, artinya dapat pengaruh secara bersama-sama variabel perencanaan strategi, kinerja perusahaan terhadap keunggulan bersaing.

Uji Koefisien Determinasi $\left(\mathrm{R}^{2}\right)$

Ghozali dalam penelitian Jamilah koefisien determinasi $\left(\mathrm{R}^{2}\right)$ pada intinya mengukur seberapa jau kemampuan model dalam menerangkan variasi variabel dependen.

${ }^{21}$ Ibid ghozali, hlm,105 
Uji koefisien Determinasi $\left(\mathrm{R}^{2}\right)$

\begin{tabular}{|l|l|l|l|l|l|}
\hline $\begin{array}{l}\text { Model } \\
\text { Summary }\end{array}$ & & & & \\
\hline Model & $\mathrm{R}$ & $\begin{array}{l}\mathrm{R} \\
\text { Square }\end{array}$ & $\begin{array}{l}\text { Adjusted } \\
\text { Square }\end{array}$ & $\begin{array}{l}\text { R } \\
\text { Std. Error of the } \\
\text { Estimate }\end{array}$ & $\begin{array}{l}\text { Durbin- } \\
\text { Watson }\end{array}$ \\
\hline 1 & $.731^{\mathrm{a}}$ & .535 & .521 & 2.054 & 2.052 \\
\hline
\end{tabular}

Sumber : hasil olahan SPSS 17.0 Tahun 2019

Nilai R square atau koefisisen determinasi berkisar antara 0 sampai 1. dalam tabel 4.21 model summary diatas, angka $\mathrm{R}$ square adalah 0,535. Regresi linear berganda sebaiknya menggunakan $\mathrm{R}$ Square yang sudah disesuaikan atau tertulis Adjusted $\mathrm{R}$ Sqare, karena disesuaikan dengan jumlah variabel independen yang digunakan. Angka Adjusted R Square adalah 0,521. Artinya 52,1\% Variabel terikat yang terdiri dari keunggulan bersaing, dapat dijelaskan oleh variabel bebas yang terdiri dari perencanaan strategi, kinerja perusahaan, dan sisanya sebesar 47,9\% dijelaskan oleh variabel lain diluar variabel yang digunakan dalam penelitian ini.

Analisis Regresi Berganda

Persamaan regresi linier berganda digunakan untuk mengetahui seberapa besar pengaruh variabel bebas ( perencanaan strategi, kinerja perusahaan) secara individual memperoleh variabel terikat (keputusan keunggulan bersaing), ${ }^{22}$

Uji Regresi linear Berganda

\begin{tabular}{|l|l|l|l|l|l|l|}
\hline Model & & $\begin{array}{l}\text { Unstandardized } \\
\text { Coefficients }\end{array}$ & $\begin{array}{l}\text { Standardized } \\
\text { Coefficients }\end{array}$ & $\mathrm{T}$ & Sig. \\
\hline & & $\mathrm{B}$ & $\begin{array}{l}\text { Std. } \\
\text { Error }\end{array}$ & Beta & & \\
\hline 1 & (Constant) & 9.363 & 2.136 & & 4.385 .000 \\
\hline & PS & .330 & .081 & .516 & 4.055 .000 \\
\hline & KP & .277 & .136 & .259 & 2.036 .046 \\
\hline
\end{tabular}

Sumber: hasil olahan SPSS 17.0 Tahun 2019

22 Sujarweni wiratna, 2015, SPSS Untuk penelitian, Yogyakarta: Pustaka Baru Press 
Berdasarkan hasil perhitungan pada tabel diatas dengan menggunakan alat bantu SPSS 17.0 tahun 2019 dapat diketahui bahwa persamaan regresi linier berganda adalah :

$Y=9,363+0,330 x 1+0,277 \times 2$

persamaan regresi tersebut dapat dijelaskan sebagai berikut :

Konstanta sebesar 9,363 menyatakan bahwa jika variabel independen dianggap konstan, maka keunggulan bersaing sebesar 9,363.

Koefisien regresi variabel perencanaan strategi (x1) sebesar 0,330 artinya jika variabel independen lain nilai nya tetap dan variabel perencanaan strategi (x1) ditingkatkan sebesar satu-satuan maka variabel keungglan bersaing (y) meningkat sebesar 0,330. Dapat disimpulkan bahwa variabel perencanaan strategi berpengaruh terhadap keunggulan bersaing. jika perencanaan strategi meningkat satu-satuan maka akan meningkatkan keunggulan bersaing sebesar 0,330 (33,0\%)

Koefisien regresi variabel kinerja perusahaan (x2) sebesar 0,277 artinya jika variabel independen lain nilainya tetap dan variabel kinerja perusahaan, maka variabel keunggulan bersaing (y) meningkat sebesar 0,277. Dapat disimpulkan bahwa variabel kinerja perusahaan meningkat satu-satuan maka akan meningkatkan keunggulan bersaing sebesar 0,277 (22,7\%).

\section{PEMBAHASAN}

A. Pengaruh Perencanaan Strategi Terhadap Keunggulan Bersaing

Berdasarkan hasil pengelohan data yang telah dilakukan dengan menggunakan program SPSS 17.0 tahun 2019 menunjukkan bahwa Perencanaan Strategi berepengaruh secara signifikan terhadpa keunggulan bersaing yang dilihat dengan hasil pengujian uji $t_{\text {hitung }}$ sebesar 4,055 dengan tingkat signifikansi $0,000<0,005$ dan sedangkan nilai t tabel sebesar 1,994. Hal ini berarti nilai $\mathrm{t}_{\text {hitung }}>\mathrm{t}$ tabel. dengan demikian dapat diambil kesimpulan bahwa Ho ditolak, artinya perencanaan strategi berpengaruh signifikan secara individu terhadap keunggulan bersaing. Pengaruh yang dihasilkan oleh strategic planning terhadap competitive advantages adalah positif yang berarti bahwa semakin baik penerapan strategic planing yang dilakukan perusahaan akan menjadikan competitive advantages perusahaan semakin baik. Li et.al (2006, 
p.111) mengatakan bahwa keunggulan bersaing adalah keadaan di mana perusahaan dapat menciptakan posisi pertahanan yang baik atas pesaingpesaingnya. Myran (2012) melakukan penelitian tentang hubungan antara perencanaan strategis dengan keunggulan bersaing perusahaan pada bank yang ada di Jordania. Hasil penelitian yang dilakukan menunjukkan bahwa perencanaan strategis yang dilakukan mempunyai hubungan positif dan signifikan dengan keunggulan bersaing. Berarti semakin baik perencanaan strategik dilakukan, maka perusahaan akan memiliki keunggulan kompetitif yang lebih baik.

\section{B. Pengaruh Kinerja Perusahaan Terhadap Keunggulan Bersaing}

Berdasarkan hasil pengelolaan data yang telah dilakukan dengan menggunakan program SPSS 17.02019 menunjukkan bahwa kinerja perusahaan berpengaruh secara signifikan terhadap keunggulan bersiang, dibuktikan dari hasil pengujian statistik uji t diperoleh nilai $\mathrm{t}_{\text {hitung }}$ sebesar 2,036 diatas dari nilai $\mathrm{t}$ tabel 1,994 dengan nilai signifikansi 0,046 $<0,05$ dengan demikian dapat diambil kesimpulan bahwa Ho ditolak, artinya kinerja perusahaan berpengaruh signifikan secara individu terhadap keunggulan bersaing.

C. Pengaruh Perencanaan Strategi dan Kinerja Perusahaan Secara Simultan Terhadap Keunggulan Bersaing pada Toko Busan Muslim.

Berdasarkan hasil olahan SPSS 17.0 2019 menunjukkan bahwa nilai signifikansi 0,00 lebih kecil dari taraf nyata 0,05. Berdasarkan kedua perbandingan tersebut, maka Ho ditolak H3 diterima. Kesimpulannya adalah Perencanaan Strategi dan Kinerja Perusahaan berpengaruh signifiikan secara simultan terhadap keunggulan bersaing yang dilihat dengan hasil pengujian regeresi dengan tingkat signifikansi $0,00<0,05$ dan F-Statistik bernilai positif $(38,493)$.

Mengingat perkembangan bisnis saat ini sangat dinamis, sering berubah-ubah, preferensi konsumen terhadap produk atau jasa sering mengalami perubahan, begitu juga pesaing dalam bisnis sering kali bergantiganti, adanya perencanaan strategik yang baik akan dapat membantu perusahaan untuk mengembangkan strategi yang efektif, meningkatan kinerja perusahaan, menangani secara efektif perubahan keadaan, 


\section{KESIMPULAN}

Berdasarkan uraian-urain dan pembahasan pada bab sebelumnya maka kesimpulannya yang dapat di ambil adalah sebagai berikut:

Perencanaan Strategi berpengaruh secara signifikan terhadap keunggulang bersaing yang dapat dilihat dengan hasil pengujian regresi dengan tingkat signifikansi $0,000<0,05$ dan t-Statistik bernilai positif $(0,330)$ Artinya apabila variabel Perencanaan Strategi mengalami kenaikan maka variabel keunggulan bersaing mengalami kenaikan sehingga variabel keunggulan bersaing akan mengalami hal yang sama yaitu kenaikan sebesar 33,0\%., Kinerja Perusahaan berpengaruh secara signifikan terhadap keunggulan bersaing, dapat dilihat dengan hasil pengujian regresi dengan tingkat signifikansi $0,046<0,05$ dan t-Statistik bernilai positif sebesar $(0,277)$, artinya apabila variabel kinerja perusahaan mengalami kenaikan maka variabel keunggulan bersaing akan mengalami hal yang sama yaitu kenaikan sebesar 27,7\%. Perencanaan Strategi dan Kinerja Perusahaan berpengaruh signifikan secara simultan akan meningkatkan keunggulan bersaing yang dapat dilihat dari hasil pengujian regersi dengan tingkat signifikansi $0,00<0,05$ dan FStatistik bernilai positif $(38,493)$, artinya apabila menerapkan perencanaan strategi dan kinerja perusahaan secara bersama-sama maka akan meningkatkan keunggulan bersaing sebesar $(38,49 \%)$

\section{SARAN}

Berdasarkan pada kesimpulan-kesimpulan yang diambil, maka selanjutnya dapat diusulkan beberapa saran yang mungkin dapat dilakukan dan bermanfaat sebagai berikut: Meningkatkan Strategic planning yang dapat membantu perusahaan untuk mengembangkan strategi yang efektif, dalam menangani secara efektif perubahan keadaan, dan mengantisipasi masalah masa depan yang peluang yang ada.,Melakukan upaya peningkatan kinerja perusahaan menjadi lebih baik lagi kedepannya. Dua aspek yang mungkin perlu diperhatikan oleh perusahaan, yaitu lebih meningkatkan efektifitas dan efisiensi penggunaan sumber daya agar mencapai biaya produksi yang telah ditargetkan sehingga dengan harga produk yang terjangkau tersebut maka perusahaan akan mampu mencakup lingkup pasar lebih luas lagi untuk meningkatnya kinerja perusahaan. 


\section{DAFTAR PUSTAKA}

Arikunto, S. 2006. Metode Penelitian Kualitatif. Jakarta: Bumi Aksara

Arasa, R., K'Obonya. P. (2012). The Relationship between Strategic Planning and Firm Performance. International Journal of Humanities and Social Science, Vol. 2 No. 22, 201-2013.

A. P. Mangkunegara. 2016. Manajemen Sumber Daya Manusia Perusahaan. Bandung: PT. Remaja Rosdakarya.

Bryson., J., M, (2001). Perencanaan Strategis Bagi Organisasi Sosial, Pustaka Pelajar Yogyakarta

Dirgantoro, crown, (2001). Manajemen stratejik konsep, kasus dan implementasi. Grasindo, jakrta

Ghazali, Imam. (2011). Aplikasi Analisis Multivariate Dengan Program IBM SPSS 19. Uneversitas Diponegoro. Semarang.

Husein Umar. 2012. Metode Penelitian untuk Skripsi dan Tesis. Jakarta: Rajawali

Istanto., Y, (2010), Pengaruh Strategi Keunggulan Bersaing dan Positioning Terhadap Kinerja. Buletin Ekonomi, V01 8 (2) 124-135.

Kurniawan, A., Nurdin, B., \& Indrianty, S. (2019). Analisis Pengaruh Faktor Manajerial, Faktor Lingkungan, Kultur Organisasi Dan Perencanaan Strategis Terhadap Keunggulan Bersaing PT Semen Tonasa.

Muhammad Munir \& Wahyu Ilahi. 2006. Manajemen Dakwah. jakarta: Kencana Prenada media group.

Mahsun. (2014) Teks dalam Pembelajaran Bahasa Indonesia. Jakarta: Raja Grafindo Persada 
Natasha, P \& Devie. (2013). Analisa Pengaruh Strategic Planning Terhadap Keunggulan Bersaing dan Kinerja Perusahaan. Bussines accounting review, Vol 1(2), 185-195.

Noor, juliansyah. (2011) Metodologi Penelitian: Skripsi, Tesis, Disertasi, dan Karya Ilmiah. Jakarta: Kencana

Nurma., M, (2013). Strategi Keunggulan Bersaing Untuk Meningkatkan Jumlah Nasabah di PT, PBRS Mitra Cahaya Indonesia Ngalik Sleman. Skripsi Universitas Islam Negri Sunan Kalijaga Yogyakarta. (2013).

Rivai dan Basri. (2005) manajemen sumber daya manusia untuk perusahaan, Jakarta: Rajagrafindo Persada

Rusniati \& Ahsanul H. (2014). Perencanaan Strategi dalam Perspektif Organisasi. Jurnal INTEKNA, Vol 2 (2), 102-209.

Sugiyono, (2014). Metode Penelitian Kuantitatif Kualitatif dan R\&D. Bandung: Alfabeta.

Sugiyono, (2015). Metode Penelitian Pendekatan Kuantitatif, Kualitatif dan R\&D. Alfabeta 